\title{
PENGEMBANGAN KREATIVITAS BERPIKIR ANAK USIA DINI DENGAN PERMAINAN BAHASA
}

\author{
Oleh: \\ Aushofil Karimah ${ }^{1}$ \\ Fakultas Tarbiyah IAI Ibrahimy Situbondo \\ aushavie246@gmail.com
}

\begin{abstract}
:
Profesional education say education at an early age will determine the future success and a personality in the future. Therefore it have to care seriously and give an good education to develop the knowledge and skills of children at an early age at each stage of his development.
\end{abstract}

Key words: Perkembangan Kreativitas, Bahasa, Anak Usia Dini

\section{A. Pendahuluan}

Pendidikan Anak Usia Dini adalah pendidikan yang dilaksanakan pada usia dini, yaitu pada rentang usia 0-6 tahun. Program dalam Pendidikan Anak Usia Dini diharapkan dapat membantu meletakkan dasar ke arah perkembangan sikap, pengetahuan, keterampilan dan kreativitas anak. Selain itu, beberapa hal yang perlu diingat adalah bahwa masa kanak-kanak adalah masa yang peka untuk menerima berbagai macam rangsangan dari lingkungannya, termasuk lingkungan sekolah. Masa kanak-kanak juga masa bermain, karena itu pembelajaran pada anak usia dini dilaksanakan dengan cara bermain sambil belajar. ${ }^{2}$

Kreativitas sangat diperlukan dalam kehidupan manusia. Semua yang ada saat ini adalah hasil kreativitas berpikir manusia. Dengan otak yang aktif dan kreatif dalam berpikir, maka timbullah ide-ide cemerlang dan menghasilkan sesuatu yang luar biasa. Seperti contoh ; bagaimana Wright bersaudara berusaha membuat pesawat pertama karena terinspirasi dari burung yang terbang di angkasa, bagaimana helicopter tercipta karena meniru bentuk capung, dan masih banyak hal-hal luar biasa lainnya yang menunjukkan kreativitas manusia dalam berpikir.

Pada dasarnya, kreativitas secara umum mencakup tiga hal, yaitu kognitif (berpikir), afektif (sikap dan kepribadian), dan psikomotor

\footnotetext{
${ }^{1}$ Alumnus Graduate School UIN Sunan Kalijaga Yogyakarta,

2 Yeni Rachmawati \& Euis Kurniati, Strategi Pengembangan Kreativitas Pada Anak, (Jakarta: Kencana Prenada Media Group, 2010), hlm. 1 
(keterampilan dan perilaku) ${ }^{3}$. Dalam bahasan ini penulis memfokuskan pada ranah kognitif (berpikir), karena berpikir dan pikiran adalah potensi yang diberikan Tuhan untuk terus dikembangkan, dan alat untuk pengembangan berpikir itu adalah otak.

Aktif dan kreatif berpikir merupakan akar dari segala sesuatu, karena dengan hasil pikiran kita dapat menghasilkan sesuatu yang berharga, dapat menciptakan sesuatu yang luar biasa, dan dapat menuntun perilaku kita dalam bersikap. Selain itu, dengan berpikir aktif dan kreatif juga menunjukkan bahwa otak yang dibekalkan Tuhan kepada manusia dapat dipergunakan dengan baik, karena pada dasarnya manusia dibekali dengan potensi kreatif dengan otak sebagai alat berpikir, sehingga dapat menciptakan peradaban agung di muka bumi ini.

Bermain adalah sarana untuk belajar yang tepat pada anak usia dini. Dengan bermain, apapun mainannya, anak dapat mengembangkan pengetahuan dan kreatifitasnya sehingga anak juga dapat menciptakan sesuatu dari benda yang ada di sekitarnya sesuai dengan apa yang ada dalam pikirannya. Akan tetapi permainan juga memiliki masa, dalam merangsang anak dengan permainan-permainan juga perlu diperhatikan jenjang usia anak tersebut, sehingga dapat menggunakan mainan sebagai hiburan dan alat belajar dengan maksimal.

Pada anak usia TK, bermain dengan bahasa yang berupa gambar atau kata-kata diharapkan dapat merangsang daya kreatif dalam berpikir. Karena dengan distimulus dengan kata-kata atau sebuah gambar, diharapkan -setidaknya- anak dapat dengan cepat mengidentifikasi benda tersebut dan dapat mengembangkan pikiran atau imajinasinya atas benda tersebut.

Anak kreatif memiliki seribu-satu jalan, mengingat cara berpikir anak kreatif yang divergen (nyeleneh). Dengan pikiran yang divergen itu anak dapat menemukan keunikan-keunikan ide. Sikapnya senantiasa penasaran dan ulet menemukan jawaban atas permasalahan yang

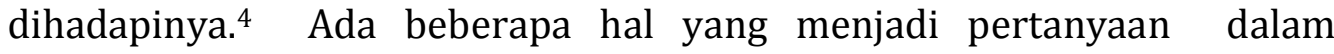
penenelitian ini, Bagaimana strategi pengembangan kreativitas berpikir anak dan Permainan-permainan bahasa apa saja yang dapat digunakan untuk mengembangkan kreativitas berpikir anak?.

Penelitian ini merupakan field research yang dilakukan untuk

3 Utami Munandar, Pengembangan Kreativitas Anak Berbakat, (Jakarta: PT. Rineka Cipta, 2009), hlm. 1

${ }^{4}$ Andang Ismail, Education Games, (Yogyakarta : Pro-U Media, 2009), hlm. 225.

164 JURNAL LISAN AL-HAL 
mengumpulkan dan mengolah data untuk dapat menjawab masalahmasalah pokok yang diajukan dalam penelitian. Sifat penelitian ini adalah deskriptif analitik. Penelitian ini berusaha memaparkan konsep-konsep pemikiran tentang pengembangan kreativitas anak usia dini secara umum yang diperoleh dari hasil kajian pustaka dan kajian lapangan, kemudian dideskripsikan dan dilakukan analisis dengan mengkolaborasikan data yang diperoleh di lapangan dengan pemikiran para pakar pendidikan tentang konsep pengembangan kreativitas pada anak usia dini.

\section{B. Child Creativity Development}

Kreativitas adalah kata yang memiliki arti yang luas. John M. Echols dalam An English-Indonesian Dictionary menuliskan; creativity (kreativitas) adalah daya cipta, yang memiliki kata dasar creative atau daya cipta5.

Dalam kamus oxford (The Oxford English Dictionary) menjelaskan kreativitas sebagai:

"Being imaginative and inventive, bringing into existence, making, originating" (menjadi imajinatif/penuh daya hayal dan inventif/penuh daya cipta, masuk dalam eksistensi, mencipta, melahirkan/ memurnikan). (Concise Oxford Dictionary, $9^{\text {th }}$ edition, 1995) ${ }^{6}$

Menurut James J Gallager, mengatakan bahwa : "Creativity is a mental process by which an individual creates new ideas and products, or recombines existing ideas and product in fashion that is novel to him or her" (kreativitas merupakan sebuah proses mental yang dilakukan individu berupa gagasan ataupun produk baru, atau mengombinasikan antara keduanya yang pada akhirnya akan melekat pada dirinya). ${ }^{7}$

Elizabeth B. Hurlock dalam bukunya yang berjudul Perkembangan Anak kemudian menguraikan beberapa arti kreativitas yang populer digunakan. Ada delapan arti dari kreativitas yang populer digunakan sebagai berikut:

Pertama, salah satu arti kreativitas yang populer menekankan pembuatan sesuatu yang baru dan berbeda. Kebanyakan orang menganggap kreativitas dapat dinilai melalui hasil atau apa saja yang diciptakan seseorang. Akan tetapi kreativitas tidak selalu membuahkan

${ }^{5}$ John M. Echols dan Hassan Shadily, Kamus Inggris Indonesia (Jakarta: PT. Gramedia Pustaka Utama, 2000, London: Cornell University Press), hlm. 154.

${ }^{6}$ Anna Craft, Me-Refresh Imajinasi dan Kreativitas Anak, dari judul asli: Creativity Across The Primary Curriculum, (Jakarta: Cerdas Pustaka, 2004), hlm. 9.

${ }^{7}$ Yeni, Strategi Pengembangan.., hlm. 13. 
hasil yang dapat diamati dan dinilai. Dengan demikian, kreativitas harus dianggap sebagai suatu proses- suatu proses adanya sesuatu yang baru.

Arti kedua yang populer dari kreativitas memandangnya sebagai kreasi sesuatu yang baru dan orisinal secara kebetulan, sebagaimana seorang anak yang bermain dengan balok-balok kayu, membangun tumpukan yang menyerupai rumah dan kemudian menyebutnya rumah.

Konsep kreativitas ketiga yang populer menyatakan bahwa apa saja yang diciptakan selalu baru dan berbeda dari yang telah ada dan karenanya unik. Terdapat banyak bukti bahwa konsep ini tidak benar atau hanya benar sebagian. Diakui bahwa semua kreativitas mencakup gabungan dari gagasan atau produk lama ke dalam bentuk baru, tetapi yang lama merupakan dasar bagi yang baru. Selanjutnya, keunikan meripakan prestasi yang sifatnya pribadi, namun belum tentu merupakan prestasi yang universal.

Gagasan populer keempat dari kreativitas adalah bahwa ia merupakan proses mental yang unik, suatu proses yang semata-mata dilakukan untuk menghasilkan sesuatu yang baru, berbeda dan orisinal. Menurut Guilford pemikiran berbeda (divergent thinking) menyimpang dari dari jalan yang telah dirintis sebelumnya dan mencari variasi, dan sebagainya. Kelima, kreativitas sering kali dianggap sinonim dengan kecerdasan tinggi. Akan tetapi pada kenyataannya kreativitas hanya salah satu aspek kecerdasan seperti ingatan atau penalaran.

Keenam, kreativitas adalah sedikit kejeniusan yang diwariskan pada seseorang yang tidak ada kaitannya dengan belajar atau lingkungan yang menyatakan, akan tetapi terdapat bukti bahwa jika orang ingin kreatif maka mereka memerlukan pengetahuan yang diterima sebelum mereka dapat menggunakannya dengan cara yang baru atau orisinil.

Ketujuh, kreativitas umumnya dianggap sinonim dengan imajinasi serta fantasi, dan karenanya kreativitas dianggap sebagai bentuk permainan mental. Dan Goldner mengungkapkan kreativitas adalah "kegiatan otak yang teratur, komprehensif, imaginative menuju hasil yang orisinal".

Konsep yang kedelapan adalah membagi anak menjadi dua golongan, yaitu "penurut" dan "pencipta". Anak kreatif adalah anak yang masuk dalam golongan pencipta (creators) yang yang menyertakan gagasan orisinal, titik pandang yang berbeda, atau cara baru dalam menangani masalah dan menghadapinya.

Di sini disebutkan bahwa orang yang kreatif suka mengutak-atik segala sesuatu secara mental dan mencoba berbagai kemungkinan bahkan 
juga ketika mereka salah. Karakteristik pemikiran berbeda lainnya ialah "meloncat-loncat". Ia tidak bergerak dalam tahapan yang mudah diamati dan didefinisikan. ${ }^{8}$

John W. Santrock mengatakan kreatif adalah kemampuan untuk berpikir dalam cara-cara yang baru dan tidak biasa serta menghasilkan pemecahan masalah yang unik. ${ }^{9}$

Al-Maushu'ah al-Falsafiyyah al-'Arabiyyah (Ensiklopedia Filsafat Arab) mendefinisikan kreativitas sebagai membuat sesuatu yang baru atau menyusun unsur-unsur baru dalam bentuk yang baru. Sedangkan Ensiklopedi Inggris Modern mendefinisikan kreativitas sebagai kemampuan untuk menciptakan sesuatu yang baru, seperti solusi untuk suatu masalah atau penampilan baru, nilai seni, atau metode baru. ${ }^{10}$

Prof. Dr. Utami Munandar dalam bukunya yang berjudul Pengembangan Kreativitas Anak Berbakat mengatakan bahwa kreativitas adalah daya cipta yang memungkinkan penemuan-penemuan baru dalam bidang ilmu dan teknologi, serta dalam semua bidang usaha manusia. ${ }^{11}$

Selanjutnya Munandar mengungkapkan kreativitas adalah kemampuan untuk membuat kombinasi baru berdasarkan data, informasi atau unsur-unsur yang ada. Secara operasional, kreativitas dapat dirumuskan sebagai kemampuan yang mencerminkan kelancaran, keluwesan (fleksibilitas), dan orisinalitas dalam berpikir, serta kemampuan untuk mengelaborasi (mengembangkan, memperkaya, memperinci) suatu gagasan. ${ }^{12}$

Dalam bukunya yang berjudul Mengembangkan Kreativitas, David Campbell menuliskan bahwa kreativitas adalah kegiatan yang mendatangkan hasil yang memiliki sifat sebagai berikut:

a. Baru (novel) : inovatif, belum ada sebelumnya, segar, menarik, aneh, mengejutkan.

b. Berguna (useful) : lebih enak, lebih praktis, mempermudah, memperlancar, mendorong, mengembangkan, mendidik, memecahkan masalah, mengurangi hambatan, mengatasi kesulitan, mendatangkan hasil lebih baik/banyak.

\footnotetext{
${ }^{8}$ Elizabeth B. Hurlock, Perkembangan Anak jilid 2, terj. Meitasari Tjandrasa, (Jakarta: Erlangga, 2010), hlm. 2-4.

${ }^{9}$ John W. Santrock, Perkembangan Anak edisi kesebelas jilid 1, terj. Mila Rachmawati, (Jakarta: Erlangga, 2007), hlm. 342.

10 Yusuf Abu al-Hijaj, Kreatif Atau Mati, (Solo: al-Jadid, 2010), hlm. 16.

11 Utami, Pengembangan.., hlm. 6.

12 Ibid., hlm. 47.
} 
c. Dapat dimengerti (understandable) : hasil yang sama dapat dimengerti dan dapat dibuat di lain waktu.

Selanjutnya Campbell mengatakan, kegiatan kreatif mengandung perubahan arah, bagaimana gagasan-gagasan baru muncul dan berfungsi untuk mengubah situasi dan memecahkan masalah. ${ }^{13}$

Berdasarkan beberapa definisi di atas, dapat disimpulkan bahwa kreativitas merupakan suatu proses mental individu yang melahirkan gagasan, proses, metode ataupun produk baru yang efektif yang bersifat imaginatif, estetis, fleksibel, integrasi, dan berdaya guna dalam berbagai bidang untuk memecahkan suatu masalah.

Suharnan dalam Munandar mengatakan bahwa terdapat beberapa komponen pokok dalam kreativitas yang dapat dijelaskan sebagai berikut: 1). Aktifitas berpikir, kreativitas selalu melibatkan proses berpikir di dalam diri seseorang. Aktifitas ini merupakan suatu proses mental yang tidak tampak oleh orang lain, dan hanya dirasakan oleh orang yang bersangkutan. Aktifitas ini bersifat kompleks, karena melibatkan sejumlah kemampuan kognitif seperti persepsi, atensi, ingatan, penalaran, imajinasi, pengambilan keputusan, dan pemecahan masalah, 2). Menemukan atau menciptakan sesuatu yang mencakup kemampuan menghubungkan dua gagasan atau lebih yang semula tampak tidak berhubungan, kemampuan mengubah pandangan yang ada dan menggantikannya dengan cara pandang lain yang baru, dan kemampuan menciptakan suatu kombinasi baru berdasarkan konsep-konsep yang telah ada dalam pikiran. Aktifitas menemukan sesuatu berarti melibatkan proses imajinasi yaitu kemampuan memanipulasi sejumlah objek atau situasi di dalam pikiran sebelum sesuatu yang baru diharapkan muncul, 3). Sifat baru atau orisinal. Umumnya kreativitas dilihat dari adanya suatu produk baru. Produk ini biasanya akan dianggap sebagai karya kreativitas bila belum pernah diciptakan sebelumnya, bersifat luar biasa, dan dapat dinikmati oleh masyarakat. Menurut Feldman dalam Semiawan, sifat baru yang dimiliki oleh kreativitas memiliki ciri sebagai berikut: a). Produk yang memiliki sifat baru sama sekali, dan belum pernah ada sebelumnya, b). Produk yang memiliki sifat baru sebagai hasil kombinasi beberapa produk yang sudah ada sebelumnya, c). Produk yang memiliki sifat baru sebagai hasil pembaharuan (inovasi) dan pengembangan (evolusi) dari hal yang sudah ada.d). Produk yang berguna atau bernilai, suatu karya yang dihasilkan dari proses kreatif harus memiliki kegunaan tertentu, seperti

${ }^{13}$ Campbell, Mengembangkan.., hlm. 11-12.

168 JURNAL LISAN AL-HAL 
lebih enak, lebih mudah dipakai, mempermudah, memperlancar, mendorong, mendidik, memecahkan masalah, mengurangi hambatan, dan mendatangkan hasil lebih baik atau lebih banyak.

\section{Berpikir Kreatif}

Berpikir kreatif adalah sebuah proses yang dilaksanakan oleh otak yang bersifat universal, kompleks dan diatur oleh beberapa faktor, keterampilan, metode-metode yang mempengaruhinya. ${ }^{14}$ Al-Hajjaj mengungkapkan beberapa elemen yang dibutuhkan dan harus dimiliki kaitannya dengan berpikir kreatif.

Ada lima elemen yang mendasar dalam berpikir kreatif, yaitu: Kecakapan, Fleksibilitas, Originalitas, Kecakapan memberikan nilai tambah, Kepekaan terhadap masalah. ${ }^{15}$

Menurut James C. Coleman dan Counstance L. Hammen dalam Musbikin, berpikir kreatif adalah "Thinking which produce new methods, new concepts, new understandings, new inventions, new world of arts". ${ }^{16}$

Berpikir kreatif sangat dibutuhkan oleh manusia dengan kehidupannya yang kompleks. Semua yang ada saat ini adalah hasil kreativitas berpikir manusia. Dengan otak yang aktif dan kreatif dalam berpikir, maka timbullah ide-ide cemerlang dan menghasilkan sesuatu yang luar biasa. Seperti contoh bagaimana seorang arsitek dapat menciptakan bangunan bertingkat dengan berbagai bentuk seperti piramid, oval, pentagon (segi lima), dan bagaimana manusia dapat mengembangkan bermacam-macam teknologi sehingga ide pesawat terbang Wright bersaudara dapat canggih seperti yang ada sekarang. Itulah hasil kreasi manusia, hasil berpikir kreatif dan aktifnya manusia.

Aktif dan kreatif berpikir merupakan akar dari segala sesuatu, karena dengan hasil pikiran kita dapat menghasilkan sesuatu yang berharga, dapat menciptakan sesuatu yang luar biasa, dan dapat menuntun perilaku kita dalam bersikap. Selain itu, dengan berpikir aktif dan kreatif juga menunjukkan bahwa otak yang dibekalkan Tuhan kepada manusia dapat dipergunakan dengan baik, karena pada dasarnya manusia dibekali dengan potensi kreatif dengan otak sebagai alat berpikir, sehingga dapat menciptakan peradaban agung di muka bumi ini.

Berpikir kreatif berkaitan dengan perkembangan pemikiran kritis

14 Utami. Pengembangan.., hlm. 80.

15 Al-Hijaj, Kreatif atau Mati, hlm. 81-84.

16 Imam Musbikin, Dibesarkan Kantong Ajaib Doraemon, (Yogyakarta: Diva Press, 2009), hlm. 94. 
(critical thinking) yang didefinisikan secara beragam oleh para ahli. Nickerson dalam Seifert \& Hoffnung mendefinisikan pemikiran kritis sebagai "reflection or thought about complex issues, often for the purpose of choosing actions related to those issues". Sedangkan Santrock mendefinisikan "critical thinking involves grasping the deeper meaning of problems, keeping an open mind about different approaches and perspectives, not accepting on faith what other people and books tell you, and thinking reflectively rather than accepting the first idea that comes to mind"17

Dari kedua definisi tersebut dapat diambil kesimpulan bahwa berpikir kritis adalah pemahaman atau refleksi terhadap permasalahan secara mendalam, mempertahankan pikiran agar tetap terbuka untuk berbagai pendekatan dan perspektif atau pandangan yang berbeda.

Seperti yang telah disebutkan di atas, kreativitas adalah kemampuan memulai ide, melihat hubungan yang baru atau tidak terduga sebelumnya, kemampuan memformulasikan konsep yang tidak sekedar menghafal, menciptakan jawaban baru untuk soal-soal yang ada, dan mendapatkan pertanyaan baru yang perlu dijawab. ${ }^{18}$

Kreativitas ini menyangkut cara berpikir kreatif, yaitu kemampuan untuk melihat bermacam-macam jawaban terhadap satu soal. Pada anak yang berpikir kreatif, saat melihat sesuatu akan segera muncul ide-ide. Ide tersebut timbul dari dirinya sendiri tanpa perlu pemberitahuan dari orang lain.

Campbell dalam buku "Mengembangkan Kreativitas" menuliskan ada lima tahapan kreativitas dalam mencapai ide, gagasan atau pemecahan masalah secara kreatif, tahapan-tahapan tersebut adalah:

1. Preparation (persiapan)

Persiapan yaitu meletakkan dasar, mempelajari latar belakang perkara dan seluk-beluknya. Persiapan untuk kreativitas kebanyakan harus didasari oleh minat karena tidak ada hal besar yang dapat tercipta kalau tidak ada antusiasme. Selain itu persiapan kreativitas juga memerlukan "mimpi" karena dengan berani bermimpi, seseorang akan berusaha untuk mencapai mimpinya tersebut.

2. Concentration (konsentrasi) I60-161.

17 Desmita, Psikologi perkembangan, (Bandung: PT. Remaja Rosdakarya, 2010), hlm.

18 Musbikin, Dibesarkan Kantong Ajaib.., hlm. 113.

$170 \mid$ JURNAL LISAN AL-HAL 
Maksud dari konsentrasi adalah masuk sepenuhnya dalam perkara yang dihadapi. Orang yang kreatif perhatiannya tercurah dan pikirannya terpusat pada apa yang mereka kerjakan. Tahap konsentrasi merupakan lanjutan dari persiapan tetapi lebih intensif, dan merupakan pemusatan, waktu menimbang-nimbang, waktu menguji, waktu trial and error, dan sebagainya.

3. Incubation (inkubasi)

Adalah mengambil jeda waktu untuk meninggalkan masalah. Waktu mencari kegiatan yang melepaskan diri dari perkara yang sedang dihadapi. Tahap inkubasi yang merupakan lanjutan dari proses konsentrasi penting diperhatikan, karena tahapan ini merupakan saat di mana sedikit demi sedikit kita dibebaskan dari rutinitas berpikir untuk me-refresh pikiran dan perasaan.

4. Illumination (iluminasi)

Tahapan Iluminasi adalah tahapan menemukan ide, pemecahan dan penyelesaian masalah. Ketika semuanya jelas, hubungan perkara terlihat gamblang, maka jawaban atau pemecahan masalah tiba-tiba datang dalam pikiran. Hal ini merupakan puncak dari kegiatan berpikir kreatif karena jawaban yang kita cari dari suatu permasalahan, inilah saat menemukan jawaban yang (mungkin) sangat memuaskan.

5. Verivication/Production (verivikasi/produksi)

Adalah menghadapi dan memecahkan masalah secara praktis sehubungan dengan perwujudan ide atau gagasan, seperti menyusun rencana kerja dan melaksanakannya. ${ }^{19}$

\section{Relasi Kreativitas Dengan Intelegensi}

Seperti halnya kreativitas, intelegensi atau kecerdasan merupakan sebuah konsep yang sulit di definisikan. Sampai saat inipun masih belum ditemukan definisi intelegensi yang dapat diterima secara universal. ${ }^{20}$ Akan tetapi dari sekian banyak definisi tentang intelegensi yang telah dirumuskan oleh para ahli, sebagaimana yang diungkapkan Phares dalam Desmita, definisi tentang kecerdasan dapat diklasifikasikan secara umum sebagai berikut:

1. Kemampuan menyesuaikan diri dengan lingkungan, beradaptasi dengan situasi-situasi baru, atau menghadapi berbagai kondisi yang beragam.

${ }^{19}$ Campbell, Mengembangkan.., hlm. 18-20.

${ }^{20}$ Desmita, Psikologi ..., hlm. I63. 
2. Kemampuan untuk belajar atau kapasitas untuk menerima pendidikan.

3. Kemampuan untuk berpikir secara abstrak, menggunakan konsepkonsep abstrak dan menggunakan secara luas simbol-simbol dan konsep-konsep. ${ }^{21}$

Dengan memperhatikan beberapa definisi tersebut, intelegensi atau kecerdasan dapat diartikan sebagai kemampuan berpikir abstrak, memecahkan masalah dengan menggunakan symbol-simbol verbal, kemampuan untuk belajar dan menyesuaikan diri dengan pengalamanpengalaman hidup sehari-hari. ${ }^{22}$

Kecerdasan dan kreativitas bukanlah hal yang sama. Sebagian besar orang yang kreatif adalah orang yang cerdas, akan tetapi sebaliknya orang-orang yang cerdas belum tentu kreatif. ${ }^{23}$ Banyak orang yang cerdas secara akademis dan meraih nilai atau skor tinggi tetapi mereka tidak bisa menghasilkan sesuatu yang baru atau menghasilkan ide-ide yang kreatif. Hal tersebut disebabkan karena kreativitas memerlukan pemikiran yang berbeda atau divergen. ${ }^{24}$ Dari wacana tersebut dapat disimpulkan bahwa kreativitas dapat diolah dengan pemikiran-pemikiran yang "ekstrim", divergen dan dari berbagai sudut pandang, dan orang yang kreatif adalah orang yang cerdas dalam menghadapi berbagai kondisi dengan cara berpikirnya yang divergen.

Santrock menyebutkan bahwa pemikiran divergen memunculkan banyak jawaban terhadap pertanyaan yang sama. ${ }^{25}$ Orang yang kreatif dapat dipastikan ia adalah orang yang cerdas, namun tidak selalu orang yang cerdas adalah orang yang kreatif. Terciptanya sebuah karya kreatif bukan hanya memerlukan kecerdasan saja, tapi juga membutuhkan lebih dari sekedar kecerdasan yaitu kreativitas. ${ }^{26}$ Jadi secara umum dapat dikatakan kecerdasan merupakan salah satu ciri dari orang kreatif.

\section{Ciri-Ciri Anak Kreatif}

Penelitian tentang kreativitas menghasilkan dua penemuan penting yaitu; pertama menurut Perkins, bahwa individu kreatif memanfaatkan proses belajar yang sama seperti orang lain, tetapi mereka menggunakan dengan cara yang berbeda, yaitu cara yang lebih efisien dan fleksibel serta

21 Ibid.,

22 Ibid., hlm. 164.

23 Santrock.., Perkembangan Anak, hlm. 342.

24 Ibid.

25 Ibid., hlm. 343.

${ }^{26}$ Yeni, Strategi pengembangan.., hlm. 19.

$172 \mid$ JURNAL LISAN AL-HAL 
untu mencapai sasaran yang ambisius dan sering cukup beresiko. Kedua menurut Gruber, individu yang kreatif menjalani hidup dengan cara yang berbeda dari umumnya orang lain. Mereka sepenuhnya terlibat dan menjiwai pekerjaan mereka, menunjukkan kebutuhan untuk melakukan sesuatu yang baru dan mempunyai perasaan yang kuat mengenai tujuan dan sasaran akhir. Mereka secara ekstrem merenungkan aktivitas mereka, penggunaan waktu mereka, dan mutu produk mereka. ${ }^{27}$

Perilaku yang mencerminkan kreativitas alamiah pada anak usia dini dapat diidentifikasi dari beberapa ciri yang ada. Senang menjajaki lingkungan, mengamati dan memegang segala sesuatu, eksplorasi secara ekspansif dan eksesif. Rasa ingin tahunya besar, suka mengajukan pertanyaan dengan tak henti-hentinya. Bersifat spontan menyatakan pikiran dan perasaannya. Suka berpetualang, selalu ingin mendapatkan pengalamam-pengalaman baru. Suka melakukan eksperimen, membongkar dan mencoba-coba berbagai hal. Jarang merasa bosan, dan selalu ada yang ingin dilakukan. ${ }^{28}$

Guilford dalam Supriadi menyebutkan beberapa ciri dari anak kreatif yaitu: berpikir luwes (flexibility), lancar (fluency), asli (originality), dapat menguraikan (elaboration), dapat merumuskan kembali (redefinition). ${ }^{29}$

Andang Ismail dalam bukunya Education Games menyebutkan, kreativitas anak dapat diukur dengan ciri-ciri sebagai berikut : pertama, memiliki 1001 jalan, mengingat cara berpikir anak kreatif itu divergen. kedua, Memiliki etos kerja produktif, sebab lebih menekankan proses daripada hasil akhir. ketiga, Mencintai aktifitas yang mengarah pada penciptaan sesuatu yang baru (orisinal) dan berbeda. keempat, Memiliki daya kompetisi yang tinggi. Keempat, Memiliki kepercayaan diri yang kuat. Kelima, Ulet dan tabah. Keenam, Secara fisik, anak kreatif selalu "berantakan", kotor, energik, banyak keinginan, sering terluka dan cenderung usil karena kecerdikannya. ${ }^{30}$

Yeni Rahmawati menuliskan ada beberapa contoh perilaku anak cerdas yang ditunjukkan dengan skor IQ tinggi yang juga memiliki karakter kreatif sebagai berikut: pertama, Lincah dalam berpikir, yang umumnya

27 Howard Gardner, Mutiple Intelegences, terj. Alexander Sindoro, Kecerdasan Majemuk, (Batam: Interaksara, 2003), hlm. 248.

28 Mansur, Pendidikan Anak Usia Dini Dalam Islam (Yogyakarta: Pustaka Pelajar, 2009), hlm. 59.

${ }^{29}$ Supriadi, D. (2001). Kreativitas, Kebudayaan, dan Perkembangan Iptek. (Bandung: ALFABETA, 2001), hlm. 57.

${ }^{30}$ Andang, Education..., hlm. 230. 
ditandai dengan rasa ingin tahu yang besar, serta aktif dan giat dalam bertanya, cepat tanggap dalam menjawab persoalan. Contoh lain dari perilaku ini adalah kritis, tanggap terhadap sesuatu, memiliki daya ingat yang baik dan efektif, mampu berkonsentrasi dalam waktu yang lama, dinamis dalan berpikir, menyukai hal-hal yang baru yang membutuhkan pemikiran yang mendalam. Kedua, Tepat dan cermat dalam bertidak dengan memperhitungkan berbagai konsekuensi yang mungkin muncul dari pilihan tindakannya tersebut. Konsekuensi dari perilaku ni biasanya orang kreatif biasanya menunjukkan sikap yang penuh dedikasi dan senantiasa aktif dalam menjalankan tanggungjawabnya. Ketiga, Mempunyai semangat bersaing (kompetitif) yang tinggi baik terhadap diri sendiri maupun terhadap orang lain. Dengan kata lain setiap menemukan rangsangan positif maupun negative dari lingkungan orang kreatif dapat memanfaatkannya sebagai motivasi bagi dirinya sendiri. Ciri lainnya dari perilaku ini adalah sikap yang selalu ingin menemukan sesuatu yang baru, dan selalu bersikap terbuka terhadap hal-hal yang baru dan berbeda, serta biasanya menyenangi tugas tugas yang berat, sulit dan menantang. Keempat, Selalu berkeinginan untuk menjadi lebih baik (progresif). Kemampuan yang dimilikinya berupa kemampuan dalam menganalisis dan menyintesis permasalahan, diwujudkan dalam perilaku selalu ingin menemukan dan meneliti tentang sesuatu yang menarik perhatiannya. Kelima, Cepat menemukan perbedaan dan mudah menangkap yang tidak biasa yang akan dijadikannya sebagai bahan dasar untuk menemukan kreasinya sendiri. Keenam, Dapat menggunakan kesadaran yang tinggi untuk mengumpulkan informasi dengan cepat sehingga mereka dapat belajar dari pengalamannya dan memanfaatkannya dalam mengembangkan diri. Ketujuh, Memiliki kepekaan yang tinggi, responsive, memiliki empati yang tinggi. Kedelapan, Memiliki keinginan belajar yang tinggi dan tidak mudah putus asa dalam proses yang dilaluinya. Kesembilan, Tidak kaku dan memiliki spontanitas yang tinggi terhadap segala stimulant yang muncul dari lingkungannya. Hal ini dapat terlihat dari caranya melahirkan berbagai gagasan dalam menyelesaikan masalah dan memiliki aspirasi yang baik. Kesepuluh, Memiliki kemampuan bertahan untuk menghadapi frustasi sehingga tidak mudah putus asa dalam menghadapi permasalahan, memiliki rasa percaya diri yang tinggi dan mandiri. Kesebelas, Mampu mengendalikan diri, mengatur suasana hati dan menjaga beban stres agar tidak melumpuhkan kemampuan

$174 \mid$ JURNAL LISAN AL-HAL 
berpikir (stabilitas emosi yang baik). ${ }^{31}$

Sedangan Campbell mengelompokkan ciri-ciri orang kreatif menjadi tiga kategori sebagi berikut:

1. Ciri-ciri pokok: kunci untuk melahirkan ide, gagasan, pemecahan, cara baru, atau penemuan, yang meliputi: a). Mental Agility atau kelincahan mental untuk berpikir ke segala arah, kemampuan untuk bermain dengan ide-ide, konsep, lambang-lambang, kata-kata, dan sebagainya, khususnya kelincahan melihat hubungan yang tidak biasa dari berbagai ide tersebut. b). Divergen Thinking merupakan kelincahan untuk berpikir dari satu ide menyebar ke segala arah, sehingga melahirkan ide atau pemikiran yang berbeda dari apa yang umumnya dipikirkan oleh orang lain. c). Conceptual Flexibility adalah kemampuan untuk secara spontan mengganti cara memandang sesuatu, pendekatan, dan sebagainya, d). Originality adalah kemampuan menemukan ide, pemecahan masalah, atau cara kerja yang tidak biasa bahkan terkadang mengejutkan, e). Menyukai kompleksitas daripada simplisitas, bahwa orang kreatif lebih menyukai kerumitan daripada kemudahan, menyukai tantangan dan keruwetan sehingga dapat menemukan jalan yang unik untuk memecahkan masalah. ${ }^{32}$

2. Ciri-ciri yang memungkinkan: yang mampu membuat ide-ide kreatif yang sudah ditemukan mampu bertahan dan tetap hidup. Ciri ini meliputi: memiliki kemampuan untuk bekerja keras, berpikiran mandiri dan mempunyai pendapat sendiri (independent judgement), pantang menyerah, mampu berkomunikasi dengan baik, lebih tertarik pada konsep daripada hal-hal yang kecil, memiliki keingin-tahuan yang tinggi, kaya humor dan fantasi, tidak segera menolak ide atau gagasan baru, memiliki arah hidup yang mantap.

3. Ciri-ciri sampingan: yaitu ciri yang tidak langsung berhubungan dengan penciptaan atau menjaga agar ide tetap hidup, tetapi sering mempengaruhi perilaku orang-orang kreatif. Ciri ini meliputi: a). Tidak ambil pusing dengan apa yang dipikiran orang lain, b). Memiliki kekacauan psikologis, yaitu tidak mempedulikan dan tidak mengendalikan perasaan ataupun emosinya. ${ }^{33}$

\section{Pengembangan Kreativitas Pada Anak Usia Dini}

Para pendidik dan para ahli psikologi saat ini semakin

\footnotetext{
31 Yeni, Strategi Pengembangan.., hlm. 20-21.

32 Campbell, Mengembangkan.., hlm. 27-28

33 Ibid., hlm. 29
} 
menyadari bahwa dalam mempersiapkan kehidupannya di masa yang akan datang, anak-anak tidak hanya harus mengingat dan menyerap pengetahuan secara pasif, tetapi mereka perlu diajak untuk berperan secara aktif dalam pembelajaran dan berbuat lebih banyak dalam aktivitas belajar-mengajar,dan diajak untuk berpikir aktif serta kritis kaitannya dengan kreativitas berpikir anak.

Robert J. Sternber, seorang pakar Psikologi menyatakan untuk mengembangkan pemikiran kritis seorang anak, dapat dilakukan dengan hal-hal seperti berikut: 1). Mengajarkan anak menggunakan prosesproses berpikir yang benar. 2). Mengembangkan strategi-strategi pemecahan masalah. 3). Meningkatkan gambaran mental mereka. 4). Memperluas landasan pengetahuan anak. 5). Memotivasi anak untuk menggunakan keterampilan-keterampilan berpikir. ${ }^{34}$

Menurut Santrock dalam Desmita, untuk mampu berpikir secara kritis anak harus mengambil peran aktif dalam proses belajar-mengajar. Hal ini berarti anak-anak perlu mengembangkan berbagai proses berpikir aktif seperti: 1). Mendengarkan secara seksama. 2). Mengidentifikasi atau merumuskan pertanyaan-pertanyaan. 4). Mengorganisasikan pemikiranpemikiran mereka. 5). Memperhatikan persamaan-persamaan dan perbedaan-perbedaan. 6). Melakukan deduksi. 7). Membedakan kesimpulan-kesimpulan yang valid dan tidak valid. ${ }^{35}$

Selain hal tersebut Santrock menambahkan anak juga harus belajar untuk mengajukan pertanyaan-pertanyaan dan/atau penyataanpernyataan yang bersifat klarifikasi, belajar menguasai berbagai pengetahuan yang baru didapat atau baru diketahui, serta belajar melihat segala sesuatu bukan hanya dari satu sisi tetapi melihat segala sesuatu dari berbagai sudut pandang. ${ }^{36}$ Dengan demikian, jika anak telah terbiasa dengan proses tersebut, dan menemukan suatu masalah atau sesuatu yang baru, maka anak dengan cepat dapat mengidentifikasi dan menemukan solusi atas berbagai kemungkinan yang akan ditemui.

Paulo Freire, tokoh pendidikan berkebangsaan brazil (dalam Desmita) menjelaskan untuk mengembangkan kesadaran berpikir kritis anak, dalam proses belajar-mengajar, guru dan murid harus berperan sebagai pemain bersama-sama, bersama-sama memecahkan masalah, mencari dan bertanggung jawab atas segala sesuatu dalam proses

34 Desmita, Psikologi.., hlm. 162.

35 Ibid.,

36 Ibid.,

176 JURNAL LISAN AL-HAL 
pertumbuhan, saling belajar dan mengajar. Dalam proses ini terjadi dialog dan komunikasi secara horizontal.

Metode dari gaya belajar-mengajar yang seperti ini adalah dengan cara melemparkan masalah, kemudian mengajak anak didik untuk bersama-sama mencari solusi atas permasalahan tersebut. Metode ini menurut Freire dengan sendirinya akan melibatkan anak secara aktif dalam kegiatan pembelajaran, melatih anak berpikir aktif dan kritis, dan otomatis menyadarkan tentang adanya perkembangan yang terus bergerak maju. Dalam salah satu artikel disebutkan, untuk mengembangkan kreativitas pada anak usia dini dapat dilakukan antara dengan cara-cara berikut: pertama: Tidak terlalu mengontrol ekspresi kreativitasnya, kedua: Hindari kritikan yang mematikan kreatifitas, ketiga: Memberi rasa aman dan percaya diri, keempat: Menghargai Karya dan Kemampuan Anak, kelima: Memberikan Tantangan, keenam: Suasana Kondusif, ketujuh: Komunikasi, kedelapan: Menggambar. ${ }^{37}$

Salah satu cara untuk merangsang aktivitas dan kreativitas berpikir anak bisa dilakukan dengan cara melontarkan pertanyaan yang memiliki 1001 kemungkinan jawaban atau bisa juga dengan cara tebak-tebakan, sehingga anak dapat menggunakan pikirannya secara aktif dan kritis untuk menemukan jawaban atau solusi yang memungkinkan dan logis atas pertanyaan tersebut.

Pengembangan kreativitas berpikir dengan cara memberikan pertanyaan, atau bisa disebut dengan permainan bahasa yang mengandung berbagai kemungkinan jawaban, dicontohkan dalam QS. Thaahaa: 17-18 sebagaimana berikut:

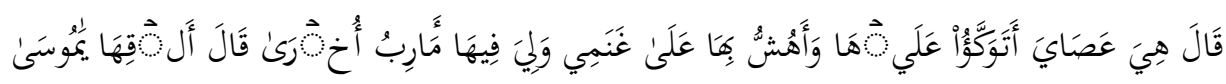

"Apakah itu yang di tangan kananmu, hai Musa? (17) Berkata Musa: "Ini adalah tongkatku, aku bertelekan padanya, dan aku pukul (daun) dengannya untuk kambingku, dan bagiku ada lagi keperluan yang lain padanya". (18)"38

Pada ayat tersebut telah jelas digambarkan Nabi Musa as. Menjawab pertanyaan yang Tuhan lontarkan dengan panjang lebar tentang fungsi dari tongkat yang dipegangnya. Dengan demikian salah satu cara dari pengembangan berpikir anak adalah dengan memberikan pertanyaanpertanyaan yang mengadung beberapa alternatif jawaban sehingga kreativitas berpikir anak dapat terlatih.

37 http://shop.littleopiie.com/artikel/19-membentuk-anak-kreatif

38 The Holy Quran Viewer 2.72, hlm. 317. 
Membentuk pola pikir cerdas dan kreatif pada seorang anak bukanlah hal yang mudah, karena dibutuhkan kesabaran dan latihan secara rutin. Menurut Imam Musbikin, anak pada usia 1-6 tahun dapat dilatih berpikir kreatif dengan cara ATM (Amati, Tiru, Modifikasi). Karena sifat anak yang paling dominan pada usia tersebut adalah mengamati dan meniru. Berikut metode ATM untuk membentuk dan melatih pola pikir kreatif anak: Amati, Cara mudah memprogram otak anak adalah dengan cara melatih mereka untuk belajar mengamati hal-hal yang ada di sekeliling mereka. Kemudian ajaklah mereka melakukan sesuatu yang menarik dan mengajarkan pada mereka segala sesuatu dengan cara yang menyenangkan. ${ }^{39}$ Dengan cara yang menyenangkan, anak-anak akan mudah menyerap pengetahuan baru dengan cepat dan menyimpannya dalam memori otaknya. Tiru, Cara kedua adalah menirukan. Cara ini sangat sering digunakan oleh anak karena anak menyusun pengetahuannya dengan cara mengamati dan menirukan ssesuatu yang ada di sekelilingnya. Dari cara belajar anak yang cenderung meniru, orang tua bisa mencontohkan kegiatan yang bermanfaat atau kegiatan-kegiatan yang positif. ${ }^{40}$ Modifikasi, Modifikasi maksudnya adalah memodifikasi dua metode di atas yaitu mengamati dan meniru. ${ }^{41}$ Ketika anak sudah bisa mengamati dan menirukan hal-hal positif yang kita lakukan, maka selanjutnya adalah mengarahkan kegiatan anak dengan dengan cara yang menyenangkan dan membuat anak merasa senang melakukannya, salah satu contohnya yaitu dengan cara bermain. Dengan cara tersebut diharapkan anak dapat menirukan setiap pekerjaan positif yang kita contohkan dengan kesadarannya sendiri bukan dengan permintaan kita.

Passmore menegaskan secara pedagogis ada beberapa hal yang bisa dilakukan oleh guru untuk membantu mengembangkan hal-hal yang bersifat imajinatif atau kreatif berpikir pada anak, yakni: 1). Guru dapat memberikan informasi-informasi kepada anak dengan beberapa alternatif metode dari penyelesaian tugas yang diberikan kepada siswa. 2). Guru dapat menyampaikan informasi kepada anak, kemudian meminta anak merefleksikan informasi tersebut sesuai dengan imajinasi mereka dengan berbagai sudut pandang. 3). Guru dapat mengajarkan kepada anak tentang berbagai alternative penyelesaian suatu masalah, sehingga anak dapat memilih solusi yang terbaik untuk menyelesaikan masalah yang

${ }^{39}$ Musbikin, Dibesarkan Kantong Ajaib.., hlm. 108.

${ }^{40}$ Ibid., hlm. 109.

${ }^{41}$ Ibid., hlm. 110.

$178 \mid$ JURNAL LISAN AL-HAL 
dilemparkan oleh guru. 4). Melatih imajinasi anak dengan pelajaran seni untuk melihat sudut pandang yang berbeda. 5). Mengamati kehidupannya sendiri setiap hari, dan meminta anak untuk menuliskan atau menceritakan pengalaman hidupnya pada hari itu. ${ }^{42}$

Cara lain yang bisa digunakan adalah dengan mengajak anak membuat mainannya sendiri dari bahan-bahan sederhana, sehingga anak merasa penasaran, semangat dan merasa perlu "menuangkan" idenya semaksimal mungkin untuk mendapatkan hasil mainan yang indah. Dan yang terpenting dalam upaya mengembangkan kreaivitas berpikir pada anak usia dini adalah dukungan atau motivasi dari lingkungan.

\section{Permainan Bahasa Untuk Pengembangan Kreativitas Anak Usia Dini}

1. Bermain, permainan, serta pentingnya bermain bagi anak

Permainan dan kreativitas dalam dunia pendidikan seringkali digabungkan, hal ini dapat ditemukan misalnya pada ketentuan pembelajaran yang disusun oleh salah satu embaga pendidikan di Amerika, bagi anak yang memasuki usia 5 tahun dan diwajibkan untuk mulai sekolah. Program yang disusun memasukkan "perkembangan kreativitas" sebagai salah satu elemennya. ${ }^{43}$

Sebagaimana yang kita tahu bahwa prinsip dasar pembelajaran pada anak usia dini adalah dilakukan dengan cara bermain sambil belajar, seperti yang tercantum dalam kerangka dasar Pendidikan Anak Usia Dini. Prinsip-prinsip Pendidikan Anak Usia Dini tersebut sebagai berikut: a). Berorientasi pada kebutuhan anak, b). Belajar melalui bermain, c). Lingkungan yang kondusif, d). Menggunakan pembelajaran terpadu, e). Mengembangkan berbagai kecakapan hidup, f). Menggunakan berbagai media edukatif dan sumber belajar, g). Dilaksanakan secara bertahap dan berulang-ulang. ${ }^{4}$

Secara psikologis dan pedagogis, bermain mempunyai nilai-nilai yang sangat berharga bagi anak di antaranya: a). Anak memperoleh perasaan senang, puas, bangga, atau berkatarsis (peredaan ketegangan), b). Anak dapat mengembangkan siap percaya diri, tanggung jawab dan kooperatif (mau bekerjasama), c). Anak dapat mengembangkan daya fantasi, atau kreativitas, terutama pada permainan fiksi dan konstruksi, d).

${ }^{42}$ Craft, Me-Refresh imajinasi.., hlm. 69-70.

43 Ibid., hlm. 61.

44 Tim Puskur Direktorat Pendidikan Anak Usia Dini, Kerangka Dasar Kurikulum Pendidikan Anak Usia Dini, (Jakarta: Departemen Pendidikan Nasional, 2007), hlm. 8-9; Jamal Ma'mur Asmani: Manajemen Strategis .., hlm. 71-73; A. Martuti, Mendirikan dan Mengelola PAUD, (Yogyakarta: Kreasi Wacana, 2009), hlm. 46-47. 
Anak dapat mengenal aturan atau norma yang berlaku dalam kelompok serta belajar untuk menaatinya, e). Anak dapat memahami bahwa baik dirinya maupun orang lain sama-sama mempunyai kelebihan dan kekurangan, f). Anak dapat mengembangkan sikap sportif, tenggang rasa dan toleran terhadap orang lain. ${ }^{45}$

Bermain bagi seorang anak tidak sekedar mengisi waktu, tetapi media untuk belajar. Setiap bentuk kegiatan bermain pada anak pra sekolah mempunyai nilai positif terhadap perkembangan kepribadiannya, di dalam bermain anak memiliki kesempatan untuk mengekspresikan sesuatu yang ia rasakan dan ia pikirkan. Dengan bermain, anak sebenarnya sedang mempraktekkan keterampilan dan anak mendapatkan kepuasan, yang berarti mengembangkan dirinya sendiri. Dalam bermain, anak dapat mengembangkan motorik kasar dan halus, meningkatkan penalaran, dan memahami keberadaan lingkungannya, membentuk daya imajinasi, daya fantasi, dan kreativitas.

Plato sebagai tokoh pertama yang menyadari pentingnya bermain menyatakan bahwa anak-anak akan lebih mudah mempelajari aritmatika dengan cara guru membagi-bagikan apel kepada anak-anak, sedangkan pemberian alat permainan miniatur balok-balok kepada anak akan mengajarkan anak tentang ilmu bangunan. ${ }^{46}$ Dengan permainan balok, dan model-model bangunan, anak akan membuat sesuatu yang baru sesuai dengan imajinasinya dan dengan bahan-bahan yang ada.

Dockeet dan Fleer berpendapat bahwa bermain merupakan kebutuhan bagi anak, karena melalui bermain anak dapat memperoleh pengetahuan yang dapat mengembangkan kemampuan dirinya. ${ }^{47}$ Dalam pendidikan anak usia dini juga disebutkan bahwa salah satu prinsip pembelajarannya adalah bermain sambil belajar. Jadi tidak bisa dipungkiri bahwa dunia anak adalah dunia bermain.

Wolfgang berpendapat bahwa terdapat sejumlah nilai-nilai dalam bermain (The value of play), yaitu bermain dapat mengembangkan keterampilan sosial, emosional, kognitif.

Dalam pembelajaran terdapat berbagai kegiatan yang memiliki dampak terhadap perkembangannya, sehingga dapat diidentifikasi bahwa fungsi bermain antara lain : pertama: Dapat memperkuat dan

45 Ibid., hlm. 173.

46 A. Martuti, Mengelola PAUD, Dengan Aneka Permainan Meraih Kecerdasan Majemuk (Yogyakarta : Kreasi Wacana, 2009), hlm. 1

47 Yuliani, Konsep Dasar Pendidikan Anak Usia Dini, (Jakarta: Indeks, 2009), hlm. 144.

$180 \mid$ JURNAL LISAN AL-HAL 
mengembangkan otot dan koordinasinya melalui gerak, melatih motorik halus, motorik kasar, dan keseimbangan, karena ketika bermain fisik anak juga belajar memahami bagaimana kerja tubuhnya, kedua: Dapat mengembangkan keterampilan emosinya, rasa percaya diri pada orang lain, kemandirian dan keberanian untuk berinisiatif, karena saat bermain anak sering bermain pura-pura menjadi orang lain, binatang, atau karakter orang lain, ketiga: Dapat mengembangkan kemampuan intelektualnya, karena melalui bermain anak sering kali melakukan eksplorasi terhadap segala sesuatu yang ada di lingkungan sekitarnya sebagai wujud dari rasa keingin-tahuannya, keempat: Dapat mengembangkan kemandiriannya dan menjadi dirinya sendiri, karena melalui bermain anak selalu bertanya, meneliti lingkungan, belajar mengambil keputusan, berlatih peran sosial, sehingga anak menyadari kemampuan dan kelebihannya. ${ }^{48}$

Association for Childhood Education International (ACEI), dan The National Association for The Education of Young Children (NAEYC), dua organisasi profesional yang membidangi masalah anak-anak, menegaskan dalam garis-garis besar pedomannya bahwa bermain adalah : 1). Memampukan anak menjelajah dunianya, 2). Mengembangkan pengertian sosial dan kultural, 3). Membantu anak-anak mengungkapkan pikiran dan perasaan mereka, 4). Memberikan kesempatan mengalami serta memecahkan masalah, 5). Mengembangkan keterampilan berbahasa dan mengenal huruf, serta mengembangkan pengertian dan konsep. ${ }^{49}$

Dengan beberapa hal tersebut di atas dapat dikatakan bahwa fungsi bermain secara umum dapat menjadi sarana anak untuk belajar dan mengenali lingkungannya, mengembangkan konsep yang berkembang dalam imajinasinya, serta mengembangkan daya kreativitasnya.

Kesenangan yang diperoleh melalui bermain memungkin anak belajar tanpa terpaksa dan tekanan sehingga disamping dapat berkembangnya motorik kasar maupun halus juga dapat dikembangkan berbagai kecerdasan yang lain secara optimal. ${ }^{50}$

Garvey menyatakan bahwa permainan terkait dengan perkembangan intelektual. Menjadi seorang fantasiser (orang yang berfantasi) yang baik, terkait dengan perkembangan kemampuan imajinasi dan intelektual. Singer memiliki hasil penelitian bahwa seorang

48 Yuliani, Konsep..., hlm. 145.

49 B. E. F. Montolalu dkk, Bermain dan Permainan Anak, (Jakarta: Universitas Terbuka, 2007), hlm. 113.

50Slamet Suyanto, Dasar-Dasar Pendidikan Anak Usia Dini (Yogyakarta: Hikayat Publishing, 2005), 128. 
anak fantasiser yang baik memiliki konsentrasi yang baik pula, dan lebih menikmati apa yang mereka lakukan daripada anak yang tidak memiliki fantasi. Tower dan Singer mengatakan anak-anak yang memiliki imajinasi dapat mengembangkan kemampuan social dan kognitif yang lebih baik, dapat mengintegrasikan pengalaman-pengalaman dengan lebih baik, dapat mempelajari perbedaan-perbedaan, dapat mengorganisasikan infomasi dengan lebih baik, serta lebih reflektif. ${ }^{51}$

Kemudian untuk mengupayakan pengembangan kreativitas berpikir pada anak usia dini, dalam penelitian ini penulis menggunakan media bermain tepatnya permainan bahasa atau dapat disederhanakan menjadi bermain dengan menggunakan kata-kata. metode ini adalah aktivitas bermain yang menggunakan bahasa atau kata-kata sebagai alatnya, seperti tebak-tebakan, menyebutkan ciri-ciri benda, menyusun kata menjadi sebuah kalimat, dan sebagainya.

\section{Bahasa}

Sebagaimana yang kita ketahui bahwa kata-kata mempunyai kekuatan untuk membantu mengarahkan pikiran anak-anak. Kata-kata akan melukiskan sebuah gambar dalam pikiran anak-anak yang akan cenderung mereka gunakan sebagai pijakan dalam bertindak. Kalimat yang kita gunakan ketika kita bicara pada anak-anak kita sangatlah penting karena kata-kata tertentu mendorong munculnya respon tertentu. ${ }^{52}$

Sedangkan devinisi bahasa itu sendiri adalah suatu bentuk komunikasi lisan atau tertulis atau isyarat yang berdasarkan pada suatu sistem dari simbol-simbol. Bahasa terdiri dari kata-kata yang digunakan oleh masyarakat beserta aturan-aturan untuk menyusun berbagai viariasi dan mengkombinasikannya. ${ }^{53}$

Bahasa memampukan kita mendeskripsikan kejadian-kejadian di masa lalu dan merencanakan masa depan. Bahasa membuat kita dapat mewariskan informasi dari satu generasi ke generasi berikutnya dan menciptakan suatu warisan budaya yang kaya. ${ }^{54}$ Bahasa juga merupakan sebuah elemen kritis dalam mengembangkan hal-hal yang bersifat

${ }^{51}$ Craft, Me-Refresh Imajinasi.., hlm. 82.

52 John K. dan Nancy F., The Miracle of Mind Power for Children, (Yogyakarta: Garailmu, 2008)

53 Santrock, Perkembangan Anak, hlm. 353.

54 Ibid.,

182 JURNAL LISAN AL-HAL 
imajinatif, baik dalam konteks permainan atau bukan. ${ }^{55}$

Para psikolog anak dan para ahli pendidikan anak menyatakan bahwa pada rentang usia 5 tahun pertama (golden age) merupakan masa kritis dalam perkembangan berbicara dan bahasa. Dalam masa ini perkembangan otak bayi dan anak sedang mengalami kemampuan maksimal dalam menyerap bahasa. Kemampuan bahasa anak tidak akan maksimal jika masa kritis ini dibiarka begitu saja tanpa melakukan stimulasi rutin pada anak.

Komunikasi dengan orang lain dapat menambah kata-kata baru dan cara mengkombinasikan kata-kata dalam pengetahuan bahasa mereka. ${ }^{56}$ Penelitian-penelitian para ahli pendidikan anak menunjukkan adanya hubungan yang kuat antara jumlah interaksi dan kualitas interaksi antara orang tua dan anak terhadap kemampuan anak berkomunikasi.

Anak membutuhkan banyak kesempatan untuk berbicara. Selain memperoleh kosakata dan tata bahasa, anak-anak harus belajar untuk terlibat dalam komunikasi yang efektif dan tepat. Orang tua, pendidik serta orang dewasa dilingkungannya merupaka model bagi anak untuk mengembangkan kemampuan bahasanya melalui percakapan sehari-hari.

Perkembangan berbahasa pada anak usia 4-6 tahun (pada usia TK) memiliki ciri sebagai berikut: pertama: Anak sudah dapat menggunakan kalimat majemuk beserta anak kalimatnya, kedua: Tingkat berpikir anak sudah lebih maju, anak banyak menanyakan soal waktu, sebab-akibat melalui pertanyaan-pertanyaan: kapan, ke mana, mengapa, dan bagaimana. 57

Untuk dapat membantu perkembangan bahasa pada anak usia dini atau kemampuan komunikasinya, orang tua dan para guru seharusnya dapat menfasilitasi, memberi kemudahan atu peluang kepada anak, misalnya dengan cara sebagai berikut: Bertutur kata yang baik dengan anak, Mau mendengarkan pembicaraan anak, Menjawab pertanyaan anak dan jangan meremehkannya, Mengajak berdialog dalam hal-hal sederhana, di sekolah anak dibiasakan untuk bertanya, mengekspresikan keinginannya, menghafal dan menyanyi, dirangsang dengan pertanyaanpertanyaan sederhana, dan lain-lain. 58

Dalam menstimulasi otak anak agar lebih kreatif, ada beberapa macam permainan bahasa yang bisa dipergunakan, antara lain

${ }^{55}$ Craft, Me-Refresh imajinasi.., hlm. 67.

56 Maimunah Hasan, PAUD (Pendidikan Anak Usia Dini), (Yogyakarta: Diva Press, 2009), hlm. 38.

${ }^{57}$ Syamsu, Psikologi perkembangan..., hlm. 170.

58 Ibid., 
sebagaimana yang disebutkan oleh As'adi Muhammad dalam bukunya "Panduan Praktis Stimulasi Otak Anak", pada anak usia 4-6 tahun dapat distimulasi dengan permainan-permainan sebagai berikut: 1). Melengkapi kalimat, 2). Menggambar dari berbagai sudut pandang, 3). Mengenal benda yang serupa dan berbeda, 4). Bermain tebak-tebakan, 5). Berlatih mengingat-ingat

\section{Kesimpulan}

Jadi pengembangan kreativitas berpikir anak dapat dilakukan dengan metode-metode khusus, sementara permainan bahasa secara umum dapat dilakukan dengan gambar, bernyanyi, menghubungkan gambar dengan kata, dan sebagainya. Metode permainan bahasa dapat dilakukan dengan menggunakan gambar-gambar atau foto dan anak diminta untuk menebak gambar dan menyanyikan lagunya, bermain tebak-tebakan, menyebutan ciri benda dan atau binatang, dan sebagainya.

\section{DAFTAR PUSTAKA}

Andrei G. A., Megaperson! 5 Petunjuk Dahsyat Menjadi Pribadi Megagenius dan Megakreatif di Lingkungan Pribadi dan Profesional terj. Gun, Yogyakarta: Garailmu, 2009

A. Martuti, Mengelola PAUD, Dengan Aneka Permainan Meraih Kecerdasan Majemuk, Yogyakarta : Kreasi Wacana, 2009.

Al-Hijaj, Yusuf Abu, Kreatif Atau Mati, Solo: al-Jadid, 2010.

Arikunto, Suharsimi, Prosedur Penelitian: Suatu Pendekatan Praktek Jakarta : Rineka Cipta, 2002.

Asmani, Jamal Ma'mur, Manajemen Strategis Pendidikan Anak Usia Dini, Yogyakarta: Diva Press, 2009.

Berk, Laura E., Development Through the Lifespan fourth edition, New York: Paerson, 2007.

Boulden, George P., Mengembangkan Kreativitas Anda, terj. Ferdinand Fuad, London: Penguin Company, 2002.

Campbell, David, Mengembangkan Kreativitas, terj. A. M. Mangunhardjana, Yogyakarta: Kanisius, 2006.

Craft, Anna, Me-Refresh Imajinasi dan Kreativitas Anak, terj. M. Chairul Annam, Jakarta: Cerdas Pustaka, 2004.

$184 \mid$ JURNAL LISAN AL-HAL 
Desmita, Psikologi perkembangan, Bandung: PT. Remaja Rosdakarya, 2010.

Echols, John M. dan Hassan Shadily, Kamus Inggris Indonesia, Jakarta: PT. Gramedia Pustaka Utama, 2000.

Gardner, Howard, Kecerdasan Majemuk, terj. Aexander Sindoro, Batam: Interaksara, 2003.

Hasan, Maimunah, PAUD (Pendidikan Anak Usia Dini), Yogyakarta: Diva Press, 2009.

Hurlock, Elizabeth B., Perkembangan Anak jilid 2, terj. Meitasari tjandrasa, Jakarta : Erlangga, 2010.

Ismail, Andang, Education Games, Yogyakarta : Pro-U Media, 2009.

John K. dan Nancy F., The Miracle of Mind Power for Children, terj. Fistaulia FS., Yogyakarta: Garailmu, 2008.

Kamus Bahasa Indonesia, Jakarta : Pusat Bahasa, DEPDIKNAS, 2008.

Madhi, Jamal, Kreatif Berpikir, Surakarta: Al-Jadid, 2009.

Majalah Bahasa dan Seni, edisi tahun 34, nomor 2, agustus 2006.

Mansur, Pendidikan Anak Usia Dini Dalam Islam, Yogyakarta : Pustaka Pelajar, 2009.

Montolalu, B. E. F., dkk., Bermain dan Permainan Anak, Jakarta : Universitas Terbuka, 2009.

Muhammad, As'adi, Panduan Praktis Stimulasi Otak Anak, Yogyakarta: Diva Press, 2010.

Munandar, Utami, Pengembangan Kreativitas Anak Berbakat, Jakarta : PT. Rineka Cipta, 2009.

Mursi, Syaikh Muhammad Said, Seni Mendidik Anak, Jakarta: Pustaka Kautsar, 2006.

Musbikin, Imam, Mendidik Anak Kreatif Ala Einstein, Yogyakarta: Mitra Pustaka, 2006. 2009.

Piaget, Jean \& Barbel Inhelder, The Psycology of the Child, terj. Miftahul Jannah, Psikologi Anak, Yogyakarta: Pustaka Pelajar, 2010.

Prasetyono, Dwi Sunar, Biarkan Anakmu Bermain, Yogyakarta: Diva Press, 2008.

Rachmawati, Yeni \& Euis Kurniati, Strategi Pengembangan Kreativitas JURNAL LISAN AL-HAL $\mid 185$ 
Pada Anak, Jakarta : Kencana Prenada Media Group, 2010.

Russell, Bertrand, Mind Power, Menjelajah Kekuatan Pikiran, terj. D. Hamdi Ridlo, Bandung: Yayasan Nuansa cendekia, 2003.

Santrock, John W., Perkembangan Anak edisi kesebelas jilid 1, terj. Mila Rahmawati, Jakarta : Erlangga, 2007.

Singarimbun, Irawati, "Teknik Wawancara" dalam Metode Penelitian Survey, Jakarta : LP3ES, 2004.

Sugiono, Memahami Penelitian Kualitatif, Bandung : CV. Alfabeta, 2005.

----------, Metode Penelitian Pendidikan : Pendekatan Kualitatif, Kuantitatif, dan R\&D, Bandung : Alfabeta, 2009.

Sujiono, Yuliani Nurani, Konsep Dasar Pendidikan Anak Usia Dini, Jakarta: Indeks, 2009.

Supriadi D., Kreativitas, Kebudayaan, dan Perkembangan Iptek. Bandung: ALFABETA, 2001.

Suyanto, Slamet, Dasar-Dasar Pendidikan Anak Usia Dini, Yogyakarta: Hikayat Publishing, 2005.

Tedjasaputra, Meike S., Bermain, Mainan, dan Permainan, Jakarta : Grasindo, 2001.

Tim PUSKUR, Kerangka Dasar Kurikulum Pendidikan Anak Usia Dini, (Jakarta: DEPDIKNAS, 2007.

---------, Naskah Akademik Kebijakan Kurikulum Pendidikan Anak Usia Dini, Jakarta: DEPDIKNAS, 2007.

Ulwan, Abdullah Nashih, Tarbiyatul Aulaad fi al-Islam jilid 2, Jakarta: Pustaka Amani, 2007.

Yusuf, Syamsu Ln., Psikologi Perkembangan Anak dan Remaja, Bandung: PT. Remaja Rosdakarya, 2011.

$186 \mid$ JURNAL LISAN AL-HAL 
"Volume 9, No. 1, Juni 2015"

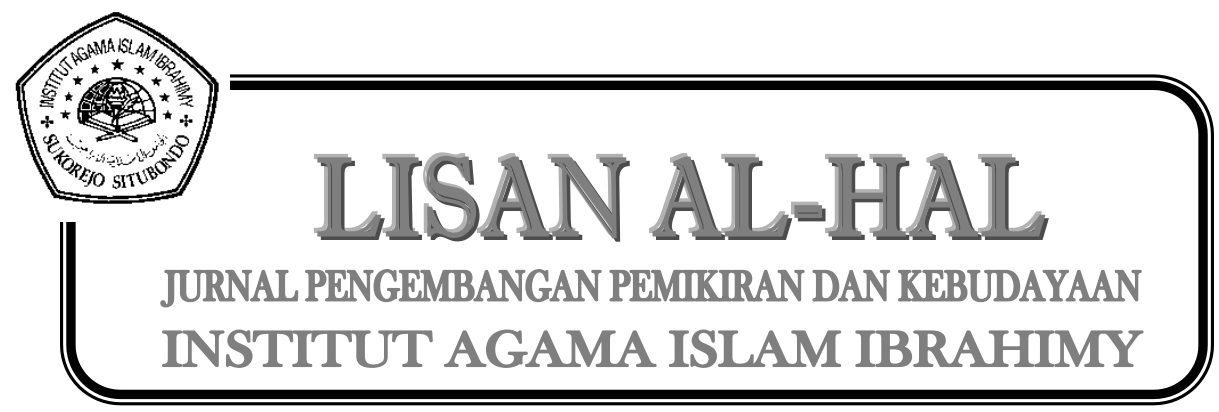

\begin{tabular}{l|l} 
JURNAL LISAN AL-HAL & 187
\end{tabular} 

